\title{
Sustainable nitrification in fluidised bed reactor with immobilised sludge pellets
}

\author{
Yilu Wang ${ }^{1}$, Weili Zhou ${ }^{1 *}$, Zhirong Li $^{1}$, Weimin $\mathrm{Wu}^{2}$ and Zhenjia Zhang ${ }^{1}$ \\ 'School of Environmental Science and Engineering, Shanghai Jiaotong University, Shanghai 200240, P.R. China \\ ${ }^{2}$ Department of Civil and Environment Engineering, Stanford University, Stanford, CA 94305-4020, USA
}

\begin{abstract}
Sustainable immobilised microbial pellets were developed with water-borne polyurethane (WPU) material together with powdered activated carbon (PAC) and activated sludge as microbial inoculums for nitrification or partial nitrification. The nitrification performance and the influencing factors were studied with lab-scale aerobic fluidised bed reactors (FBR) under various temperature conditions. During the start-up period, quickly increasing the influent ammonium concentration from 40 to $320 \mathrm{mg} \mathrm{N} \cdot \ell^{-1}$ led to a stable nitrification performance with high nitrite accumulation $(>80 \%)$. Characterisation of the FBR performance indicated that the desired partial nitrification could be achieved at $\mathrm{pH} 7.8-8.5$, dissolved oxygen (DO) 3-5 $\mathrm{mg} \cdot \ell^{-1}$ and temperature between 24 and $29^{\circ} \mathrm{C}$. Addition of organic carbon (glucose) improved the ammonium removal but decreased the nitrite accumulation ratio significantly. TOC concentration above $800 \mathrm{mg} \cdot \ell^{-1}$ was not able to cause the inhibition of the heterotrophs over the nitrifiers. PCR-DGGE results indicated the presence of Nitrosomonas (ammonia-oxidising bacteria) and Nitrobacter (nitrite-oxidising bacteria) in the immobilised pellets.
\end{abstract}

Keywords: bioimmobilisation, ammonium, partial nitrification, wastewater treatment

\section{INTRODUCTION}

The problems caused by ammonium and total nitrogen in municipal, agricultural and industrial wastewater have become a significant concern throughout the world. Discharge of high nitrogen-containing effluent to aqueous environments could cause ammonia toxicity problems and eutrophication of surface receivers. Regulatory agencies in many countries, including China, have required increasingly stringent water quality criteria for ammonium and total nitrogen $(\mathrm{TN})$ removal.

Partial nitrification, i.e., the conversion of $\mathrm{NH}_{4}{ }^{+} \mathrm{N}$ to $\mathrm{NO}_{2}{ }^{-} \mathrm{N}$ is considered as the most cost-effective biological process for further TN removal. Nitrification is a 2-stage reaction i.e. oxidation of $\mathrm{NH}_{4}^{+}-\mathrm{N}$ to $\mathrm{NO}_{2}^{-}-\mathrm{N}$ by ammonia-oxidising bacteria $(\mathrm{AOB})$ as:

$$
\begin{aligned}
& 1 / 6 \mathrm{NH}_{4}^{+}+1 / 6 \mathrm{O}_{2} \rightarrow 1 / 6 \mathrm{NO}_{2}{ }^{-}+1 / 3 \mathrm{H}^{+}+1 / 6 \mathrm{H}_{2} \mathrm{O} \\
& \left(\Delta \mathrm{G}^{0^{\prime}}=-45.79 \mathrm{~kJ} \cdot \text { reaction }{ }^{-1}\right)
\end{aligned}
$$

This followed by oxidation of $\mathrm{NO}_{2}^{-}-\mathrm{N}$ to $\mathrm{NO}_{3}^{-}-\mathrm{N}$ by nitriteoxidising bacteria (NOB) (Rittmann and McCarty, 2001) as:

$$
\begin{aligned}
& 1 / 2 \mathrm{NO}_{2}^{-}+1 / 4 \mathrm{O}_{2} \rightarrow 1 / 4 \mathrm{NO}_{3} \\
& \left(\Delta \mathrm{G}^{0}=-37.07 \mathrm{~kJ} \cdot \text { reaction }^{-1}\right)
\end{aligned}
$$

Partial nitrification involves only the first reaction and the product nitrite could be denitrified by denitrifiers in the presence of an organic electron donor source, so-called short-cut denitrification (Gao et al. 2010). Partial nitrifcation could be incorporated with anaerobic ammonium oxidation (ANAMMOX) processes (Kartal et al., 2010). Both would

\footnotetext{
To whom all correspondence should be addressed.

용 +86-21-54747461; Fax: +86-21-54740825;

e-mail:weilizhou@sjtu.edu.cn; wei_lizhou@hotmail.com

Received 1 February 2012; accepted in revised form 14 March 2013.
}

significantly reduce energy consumption for nitrate production and for providing an organic electron donor source for denitrification. Most approaches toward the achievement of partial nitrification have been reported within recent decades (Guo et al., 2010; Kim et al., 2005; Sliekers et al., 2005). Due to the higher growth rate of AOB than NOB (Munz, 2011), maintaining the predominance of $\mathrm{AOB}$ over $\mathrm{NOB}$ is one of the key factors for achieving successful partial nitrification. In order to prevent nitrite oxidation and to achieve stable partial nitrification, various approaches have been used, including addition of specific inhibitors for the NOB (Oguz, 2005), and control of the dissolved oxygen (DO) (Garrido et al., 1997) and $\mathrm{pH}$ (Ciudad et al., 2007). However, some options are not easily practicable. The inhibition of NOB may not be effective because of microbial adaptation ability. A relatively low DO is a crucial factor to achieve stable partial nitrification (Garrido et al., 1997) but a low-DO condition may cause the growth of filamentous bulking sludge (Colliver and Stephenson, 2000) or emission of the greenhouse gas nitrous oxide $\left(\mathrm{N}_{2} \mathrm{O}\right)$ via denitrification (Kampschreur et al., 2008, 2009). Other research results showed that $\mathrm{pH}$ is not a parameter which can be optimised for accumulating nitrite, as complete nitrification to nitrate occurs within a wide $\mathrm{pH}$ range, between 6.45 and 8.95 , while a $\mathrm{pH}$ lower or higher than this range may cause complete inhibition of nitrification (Ruiz et al., 2003). The growth of NOB was observed to be inhibited in the presence of high ammonia levels (Kim et al., 2005). The control of ammonia level, if possible, could provide a selection pressure for NOB.

Immobilisation of microbial cells is one of the approaches used to keep the target cells in a bioreactor, without undesired washout, and has been intensively investigated, especially for industrial fermentation products, since the late 1960's. Immobilisation by encapsulation or entrapment of cells in polymer gel-matrix is distinct from microbial granulation which occurs as a result of the action of microbial materials (Hickey et al., 1998; Liu and Tay, 2004). The most active investigation of microbial cell immobilisation (Cassidy et al., 1996) has focused 

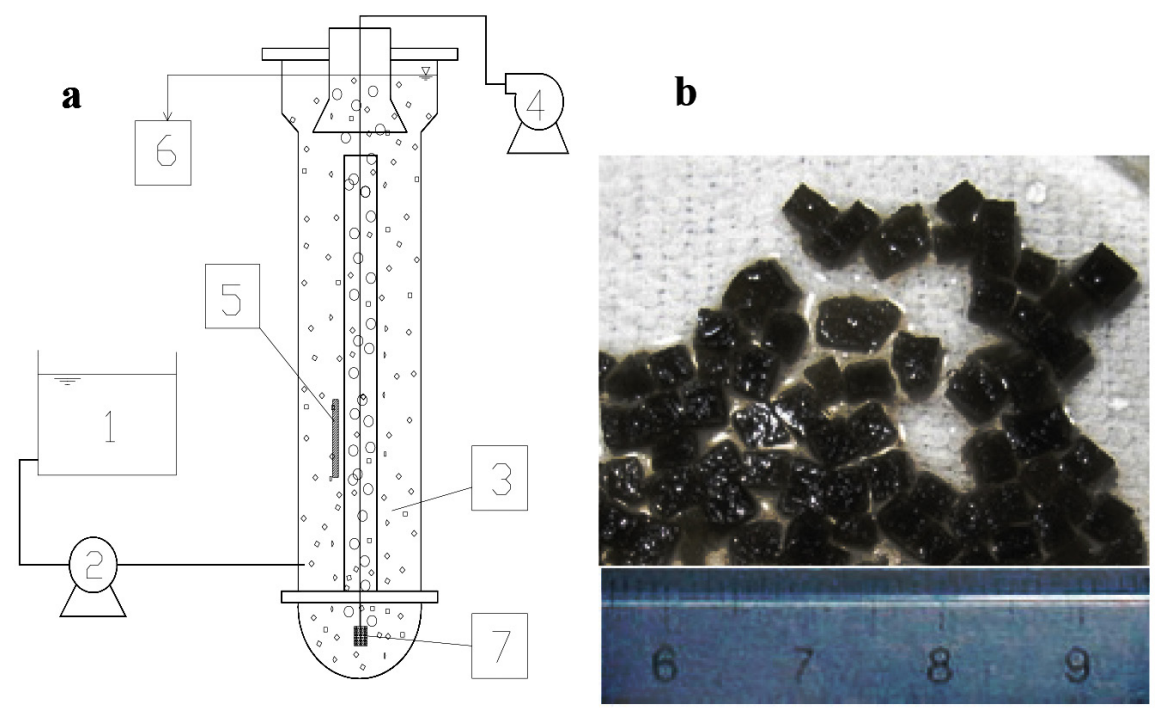

Figure 1

(a) Diagram of fluidised bed reactor with

(b) immobilised microbiological pellets

1. influent tank;

2. pump;

3. reactor and

immobilised pellets;

4. air pump;

5. temperature controller;

6. effluent;

7. aerator

on the chemical immobilisation of target functional microorganisms, which is particularly effective for enabling immediate reactor start-up. To date, a number of immobilisation methods have been tested, from lab-scale to large-scale reactors (Isaka et al., 2007; Li et al., 2006). Both natural and synthetic polymers have been used for microbial encapsulation. Natural polymers are generally less stable and not suitable for long-term use in wastewater treatment. The synthetic polymers, including polyacrylamide, polystyrene, polyurethane and polyethylene glycol, have been widely tested for environmental applications (Cassidy et al., 1996; Qiao et al., 2010).

The objective of this study was to achieve long-term, stable partial nitrification with immobilised cells. The quick increase of the influent $\mathrm{NH}_{4}{ }^{+} \mathrm{N}$ concentration functioned as selection pressure to achieve an AOB-predominated microbial community. The biomass developed was characterised by batch tests for the transformation of nitrogen $\left(\mathrm{NH}_{4}^{+}-\mathrm{N}, \mathrm{NO}_{2}^{-}-\mathrm{N}\right.$ and $\left.\mathrm{NO}_{3}^{-}{ }^{-} \mathrm{N}\right)$ and by PCR-DGGE method.

\section{EXPERIMENTAL}

\section{Synthetic wastewater}

The synthetic wastewater was prepared with tap water and the raw water of $40 \mathrm{mg} \mathrm{N} \cdot \ell^{-1}$ contained: $\mathrm{NH}_{4} \mathrm{Cl}, 152.8 \mathrm{mg} \cdot \ell^{-1}$; $\mathrm{Na}_{2} \mathrm{HPO}_{4} \cdot 12 \mathrm{H}_{2} \mathrm{O}, 46.4 \mathrm{mg} \cdot \ell^{-1} ; \mathrm{NaHCO}_{3}, 468 \mathrm{mg} \cdot \ell^{-1} ; \mathrm{NaCl}, 20.8$ $\mathrm{mg} \cdot \ell^{-1} ; \mathrm{KCl}, 9.6 \cdot \ell^{-1} ; \mathrm{CaCl}_{2} \cdot 2 \mathrm{H}_{2} \mathrm{O}, 9.6 \mathrm{mg} \cdot \ell^{-1}$; and $\mathrm{MgSO}_{4} \cdot 7 \mathrm{H}_{2} \mathrm{O}$, $33.6 \mathrm{mg} \cdot \ell^{-1} \cdot \mathrm{NH}_{4} \mathrm{Cl}$ was used as ammonium source at various concentrations as the experiment required. All chemicals were of analytically pure grade (Biomed. Co. Ltd., Shanghai, China).

\section{Reactor system}

Two identical fluidised bed reactors (FBR), i.e., Reactor A and Reactor B, were used (Fig. 1a). Each of them consisted of 2 layers of plexiglass column with an effective volume of $18 \ell$ and a height of $1.6 \mathrm{~m}$. Both were filled with $10 \%$ WPU pellets $(1.8 \ell)$. The fluidisation of the pellets was achieved in the central fluidisation zone by airlifting through the micropore aerator at the bottom. The pellets reached the top of the reactor, then were separated from air bubbles and effluent, returned to the outside reaction zone and eventually settled towards the bottom. The influent was pumped into the reactor at the bottom of the outside zone and the effluent overflowed out of the reactor after the solid-liquid separation. The FBRs were operated under aerobic conditions with an air flow rate of $60 \mathrm{l} \cdot \mathrm{min}^{-1}$.

\section{Seed sludge and immobilisation}

Activated sludge from the Suzhou Wastewater Treatment Plant, Suzhou, China, was used as inoculum for immobilised cells. Water-borne polyurethane (WPU) amended with powdered activated carbon (PAC) was used to immobilise the microbial cells. Powdered activated carbon (PAC) with diameter of 300 meshes $(48 \mu \mathrm{m})$ was added during WPU encapsulation at a ratio of $1.5 \%(\mathrm{v} / \mathrm{v})$. The solidified mixture was cut into $3 \times 3 \times 3$ $\mathrm{mm}$ granules for use. The immobilised pellets were black in colour due to the PAC content (Fig. 1b). During the acclimation and continuous tests, the operation parameters were controlled as follows: $\mathrm{pH}$ over a range of 7.8-8.5 and $\mathrm{DO}$ over a range of 3-5 mg. $\ell^{-1}$. Temperature varied from 25 to $31^{\circ} \mathrm{C}$.

\section{Reactor operation and tests}

During the continuous test, influent $\mathrm{NH}_{4}{ }^{+}-\mathrm{N}$ concentration was increased from $40 \mathrm{mg} \cdot \ell^{-1}$ to $320 \mathrm{mg} \cdot \ell^{-1}$, as soon as $\mathrm{NH}_{4}{ }^{+} \mathrm{N}$ removal efficiency of Reactor A reached $80 \%$, in order to increase the capability of the microorganisms against the shock loads. Reactor B was started up as the secondary reactor on Day 94, to treat the effluent from Reactor A.

Influence of $\mathrm{NH}_{4}{ }^{+}-\mathrm{N}$ concentration, temperature, $\mathrm{DO}$ and supplementation of organics on partial nitrification in Reactor A were studied during the continuous test period. The operational conditions of Reactor A are shown in Table 1.

\section{Batch experiments and operation conditions}

Batch experiments were designed to investigate the transformation of nitrogen during the nitrification process. The experiment was conducted in a $1.0 \mathrm{l}$ beaker. An aerator was placed at the bottom to supply oxygen and to mix the pellets. The bulk volume of the batch reactor filled with pellets was $0.1 \ell$, including voids. The substrates used in the batch tests were the same as that in the continuous tests.

Additionally, in order to evaluate the impact of organic load on nitrification performance, another batch test was carried out with initial TOC concentrations of $400 \mathrm{mg} \cdot \ell^{-1}$ and $800 \mathrm{mg} \cdot \ell^{-1}$, respectively. 


\begin{tabular}{|c|c|c|c|c|c|c|c|c|}
\hline \multicolumn{9}{|c|}{$\begin{array}{c}\text { TABLE } 1 \\
\text { The operational conditions for the continuous run }\end{array}$} \\
\hline Period & Phase & $\begin{array}{l}\text { Running } \\
\text { time (d) }\end{array}$ & $\begin{array}{l}\mathrm{NH}_{4}^{+}-\mathrm{N} \\
\left(\mathrm{mg} \cdot \ell^{-1}\right)\end{array}$ & $\begin{array}{c}\mathrm{T} \\
\left({ }^{\circ} \mathrm{C}\right)\end{array}$ & $\begin{array}{c}\mathrm{DO} \\
\left(\mathrm{mg} \cdot \ell^{-1}\right)\end{array}$ & $\begin{array}{l}\mathrm{C} / \mathrm{N} \\
\text { Ratio }\end{array}$ & $\mathrm{pH}$ & $\begin{array}{r}\text { HRT } \\
\text { (h) }\end{array}$ \\
\hline \multirow{3}{*}{ I } & 1 & $78-86$ & $340 \pm 20$ & \multirow{3}{*}{$24-25$} & \multirow{3}{*}{$3-5$} & & \multirow{3}{*}{$7.8-8.5$} & \multirow{3}{*}{4.11} \\
\hline & 2 & $88-98$ & $238 \pm 32$ & & & & & \\
\hline & 3 & 99-106 & $125 \pm 12$ & & & & & \\
\hline \multirow{3}{*}{ II } & 1 & 99-106 & \multirow{3}{*}{$125 \pm 12$} & $24-25$ & \multirow{3}{*}{$3-5$} & & \multirow{3}{*}{$7.8-8.5$} & \multirow{3}{*}{4.11} \\
\hline & 2 & $108-114$ & & $28-30$ & & & & \\
\hline & 3 & $115-120$ & & $6-11$ & & & & \\
\hline \multirow{3}{*}{ III } & 1 & $121-125$ & \multirow{3}{*}{$124 \pm 4$} & \multirow{3}{*}{$24-25$} & $4-6$ & & \multirow{3}{*}{$7.8-8.5$} & \multirow{3}{*}{4.1} \\
\hline & 2 & $126-129$ & & & $3-4$ & & & \\
\hline & 3 & $129-133$ & & & $1-2$ & & & \\
\hline \multirow{3}{*}{ IV } & 1 & $134-138$ & \multirow{3}{*}{$118 \pm 24$} & \multirow{3}{*}{$24-25$} & \multirow{3}{*}{$3-5$} & $1: 3$ & \multirow{3}{*}{$7.8-8.5$} & \multirow{3}{*}{4.11} \\
\hline & 2 & $138-140$ & & & & $1: 1.2$ & & \\
\hline & 3 & 141-144 & & & & $1: 1.7$ & & \\
\hline
\end{tabular}

\section{Analytical methods, scanning electron microscopy and calculations}

DO concentration was measured using a DO meter (HI 9143 HANNA Dissolved Oxygen Analyzer, Japan). $\mathrm{NH}_{4}{ }^{+}-\mathrm{N}^{-} \mathrm{NO}_{3}^{-}-\mathrm{N}$, $\mathrm{NO}_{2}-\mathrm{N}, \mathrm{TN}$ were analysed according to standard methods (APHA, 1995).

The preparation of the samples of the immobilised pellets in Reactor A for scanning electron microscopic examination was performed according to Zhou et al. (2006). After the freezedrying process, SEM images were produced of the immobilised pellets in Reactor A (SEM: FEI Siron 200, FEI, USA).

Free ammonia (FA) concentration was calculated using Eq. (1), proposed by Anthonisen et al. (1976):

$$
\left[\mathrm{NH}_{3}-\mathrm{N}\right]=\frac{\left[\mathrm{NH}_{4}^{+}-\mathrm{N}\right] 10^{\mathrm{pH}}}{\mathrm{e}^{6344 /(273+\mathrm{T})}}
$$

The activation energy of the nitrification reaction can be determined graphically by taking the natural logarithm of the Arrhenius equation as follows:

$$
\ln k=-\frac{E_{a}}{R T}+\ln A
$$

where:

$k$ is the reaction rate of the nitrification reaction

$A$ is the frequency factor for the reaction

$R$ is the universal gas constant $\left(8.314 \mathrm{~kJ} \cdot \mathrm{mol}^{-1} \cdot \mathrm{K}^{-1}\right)$

$T$ is the temperature in $K$

$E_{a}$ represents the activation energy.

\section{Microbial community analysis}

Pellet samples for microbial analysis were collected from Reactor A on Days 10, 18, 30, 56, 61, 81, 104, 133 and 144, and labelled as \#1 to \#9, respectively. Samples from Reactor B were collected on Days 29, 40, 52, and 92 of operation and labelled as \#10 to \#13, respectively. Samples were kept at $-70^{\circ} \mathrm{C}$ before DNA extraction.

Total bacterial DNA extraction was performed based on lyses with alkali buffer ( $\mathrm{pH}$ 9.0) containing sodium dodecyl sulphate (SDS), extraction with benzyl chloride, primary purification with sodium acetate, and collection by ethanol precipitation (Kageyama et al., 2003; Zhou et al., 2007). The extracted DNA samples were diluted 100 times with sterilised distilled water and used as the templates in PCR amplification.

The primers used for $\mathrm{AOB}$ amplification were AmoA- $1 \mathrm{~F}$ and AmoA-2R, targeting a stretch of the ammonia monooxygenase subunit A gene (amoA) (Nicolaisen and Ramsing, 2002). The primers selected for NOB amplification were the Nitrobacter-specific primer FGPS1269 and primer FGPS872 (Feray et al., 1999). For PCR amplification, the $25 \mu \ell$ reaction mixture contained $2.5 \mu \ell$ template, $200 \mathrm{nM}$ of each primer, 0.625 units of Taq DNA polymerase (Sagon, China), $200 \mu \mathrm{M}$ of dNTP mixture (Takara, Dalian), $1 \times$ PCR buffer and 1.5 $\mathrm{mM} \mathrm{MgCl}_{2}$ (Sangon, China)]. The PCR (MJ mini, Biorad, US) thermocycling regime for $\mathrm{AOB}$ was: $92^{\circ} \mathrm{C}$ for $4 \mathrm{~min}, 35$ cycles of $92^{\circ} \mathrm{C}$ for $30 \mathrm{~s}, 64^{\circ} \mathrm{C}$ for $30 \mathrm{~s}, 72^{\circ} \mathrm{C}$ for $45 \mathrm{~s}^{\cdot}$ cycle $^{-1}$; the last cycle had a final extension of $72^{\circ} \mathrm{C}$ for $10 \mathrm{~min}$. The programme for $\mathrm{NOB}$ was $92^{\circ} \mathrm{C}$ for $4 \mathrm{~min}, 35$ cycles of $92^{\circ} \mathrm{C}$ for $30 \mathrm{~s}, 53^{\circ} \mathrm{C}$ for $30 \mathrm{~s}, 72^{\circ} \mathrm{C}$ for $45 \mathrm{~s} \cdot$ cycle $^{-1}$; the last cycle had a final extension of $72^{\circ} \mathrm{C}$ for $10 \mathrm{~min}$.

DGGE of both AOB and NOB PCR products were performed with the Dcode System (BioRad, US). Polyacrylamide gels (8\%) with a gradient of $20 \%-50 \%$ denaturant, were made with a gradient maker (BioRad) according to the manufacturer's guidelines (100\% denaturing acrylamide was defined as $7 \mathrm{M}$ urea and 40\% formamide by Muyzer et al. (1993). Gels were run for $270 \mathrm{~min}$ at $200 \mathrm{~V}$ in $1 \times \mathrm{TAE}$ buffer at a constant temperature of $60^{\circ} \mathrm{C}$. The gel was stained for $20 \mathrm{~min}$ with ethidium bromide and photographed under ultraviolet light.

The representative bands of interest were excised from the polyacrylamide gels and purified by UNIQ-10 purification kit (Sangon, China) according to the manufacturer's instructions. The purified gene was used as template in the PCR re-amplification, which followed the same protocol as mentioned above. The products were purified by EZ purification kit (Sagon, China) and subjected to sequencing.

\section{RESULTS AND DISCUSSION}

\section{Acclimation and continuous test period}

The influent and effluent $\mathrm{NH}_{4}{ }^{+}-\mathrm{N}$ concentrations and $\mathrm{NH}_{4}^{+}-\mathrm{N}$ removal efficiency of the reactor $\mathrm{A}$ are presented in Fig. $2 \mathrm{a}$. It took 9 days for the reactor to reach a removal efficiency of $80 \%$. Influent $\mathrm{NH}_{4}{ }^{+}-\mathrm{N}$ concentration was increased from $80 \mathrm{mg} \cdot \ell^{-1}$ to $240 \mathrm{mg} \cdot \ell^{-1}$ after 24 days of operation, with the influent $\mathrm{NH}_{4}{ }^{+} \mathrm{N}$ 
load increasing from a minimum of $3.7 \mathrm{mg} \mathrm{NH}_{4}^{+}-\mathrm{N} \cdot \ell^{-1} \cdot \mathrm{h}^{-1}$ ) to a maximum of $88.4 \mathrm{mg}-\mathrm{NH}_{4}^{+}-\mathrm{N} \cdot \ell^{-1} \cdot \mathrm{h}^{-1}$. This rapid increase caused a consequent decrease in $\mathrm{NH}_{4}^{+}-\mathrm{N}$ removal efficiency. The efficiency declined to $75 \%$ on Day 33 . Over an 86 -day operational period, the volumetric removal rate of Reactor A remained above $9.6 \mathrm{~g} \mathrm{~N} \cdot \ell^{-1} \cdot$ pellet $^{-1} \cdot \mathrm{day}^{-1}$ and the maximum rate approached $16.76 \mathrm{~g} \mathrm{~N} \cdot \ell^{-1} \cdot$ pellet $^{-1} \cdot \mathrm{day}^{-1}$. The results indicated a higher volumetric removal efficiency and greater tolerance to the $\mathrm{NH}_{4}^{+}$-N shock loads of WPU-PAC pellets than that recorded without PAC addition in our previous study (Wang 2010).

Nitrite accumulation in Reactor A increased markedly as the influent $\mathrm{NH}_{4}^{+}-\mathrm{N}$ concentration and nitrogen loading rate increased (Fig. 2b). The majority of $\mathrm{NH}_{4}^{+}-\mathrm{N}$ was converted to $\mathrm{NO}_{2}^{-}-\mathrm{N}$ and the levels of $\mathrm{NO}_{3}^{-}-\mathrm{N}$ were very low, suggesting that the rapid increase of influent $\mathrm{NH}_{4}^{+}-\mathrm{N}$ concentration could effectively stimulate partial nitrification activity with $\mathrm{NO}_{2}^{-}-\mathrm{N}$ as predominant product.
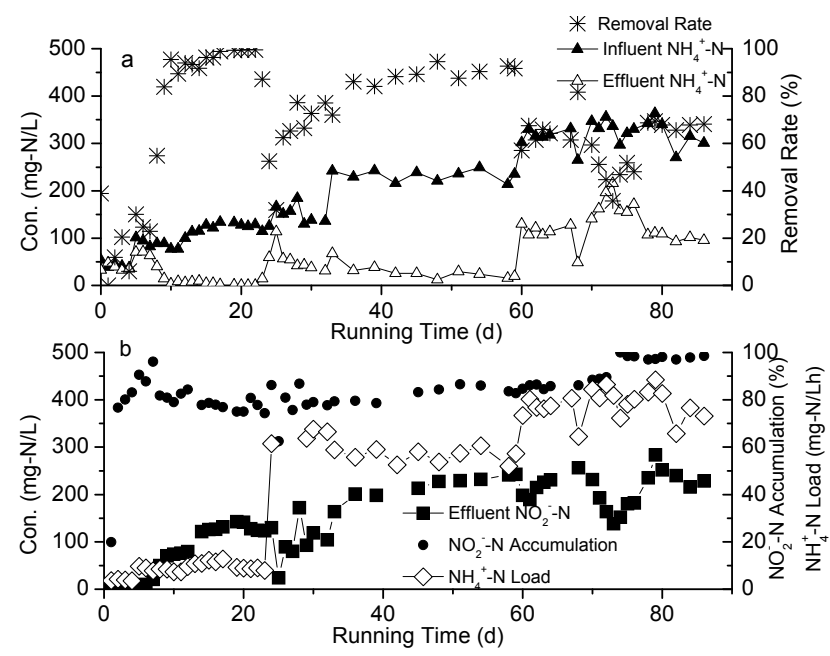

Figure 2

The nitrogen variation in Reactor $A$ during the continuous test

\section{Influence of operational conditions on partial nitrification}

The influence of 4 environmental factors on the performance of Reactor A was tested: (i) influent $\mathrm{NH}_{4}{ }^{+}-\mathrm{N}$ concentration, (ii) temperature, (iii) DO concentration, and (iv) organics concentration. Three different levels of $\mathrm{NH}_{4}{ }^{+}-\mathrm{N}(300-363,206-270$ and $\left.113-136 \mathrm{mg} \cdot \ell^{-1}\right)$ were tested from Day 1 to Day 29 (Table 1 ). The accumulation of nitrite in all cases was above $90 \%$. From Day 22 to Day 66, the influent $\mathrm{NH}_{4}{ }^{+}-\mathrm{N}$ concentration was kept at around $120 \mathrm{mg} \cdot \ell^{-1}$. As $\mathrm{NH}_{4}^{+}-\mathrm{N}^{4}$ concentration decreased from $360 \mathrm{mg} \cdot \ell^{-1}$ to $120 \mathrm{mg} \cdot \ell^{-1}$, a slight decrease of nitrite accumulation was observed (Fig. 3a), demonstrating that the higher influent $\mathrm{NH}_{4}^{+}-\mathrm{N}$ concentration facilitated the maintenance of partial nitrification.

The effect of different temperatures on partial nitrification is shown in Fig. 3b. The accumulation of nitrite was above $70 \%$ under all temperature conditions $\left(24-25^{\circ} \mathrm{C}, 28-30^{\circ} \mathrm{C}\right.$ and $6-11^{\circ} \mathrm{C}$ ). When the temperature increased from $24^{\circ} \mathrm{C}$ to $29^{\circ} \mathrm{C}$, no change in $\mathrm{NH}_{4}{ }^{+}-\mathrm{N}$ removal efficiency was observed, with the exception of a slight decrease in nitrite accumulation. However, the removal efficiency of $\mathrm{NH}_{4}^{+}-\mathrm{N}$ decreased significantly after the temperature dropped from 24 to $9^{\circ} \mathrm{C}$.

The effect of different $\mathrm{DO}$ levels on partial nitrification is shown in Fig. 3c. The $\mathrm{NO}_{2}^{-}-\mathrm{N}$ accumulation remained above $60 \%$ right after DO dropped from $5 \mathrm{mg} \cdot \ell^{-1}$ to $3 \mathrm{mg} \cdot \ell^{-1}$; meanwhile the removal efficiency of $\mathrm{NH}_{4}^{+}-\mathrm{N}$ decreased to below $40 \%$ during the same period. After DO was maintained at $3 \mathrm{mg} \cdot \ell^{-1}$ for an additional day, $\mathrm{NO}_{2}-\mathrm{N}$ accumulation rose as the removal efficiency of $\mathrm{NH}_{4}^{+}-\mathrm{N}$ was increased. The accumulation of $\mathrm{NO}_{2}-\mathrm{N}$ continued increasing as DO dropped to $2 \mathrm{mg} \cdot \ell^{-1}$.

Organics have a significant influence on the nitrification process. After organics (glucose) were supplemented at the inlet of Reactor A, at concentrations of 40, 100 and $70 \mathrm{mg} \cdot \ell^{-1}, \mathrm{NH}_{4}{ }^{+} \mathrm{N}$ removal efficiency was enhanced (above 90\%). However, the accumulation of $\mathrm{NO}_{2}-\mathrm{N}$ was decreased to near-zero after glucose was added into the reaction system (Fig. 3d), suggesting that partial nitrification changed to a complete nitrification process.

Reactor A was restarted after TOC addition. The nitrite accumulation achieved is shown in Fig. 4. After 10 days of
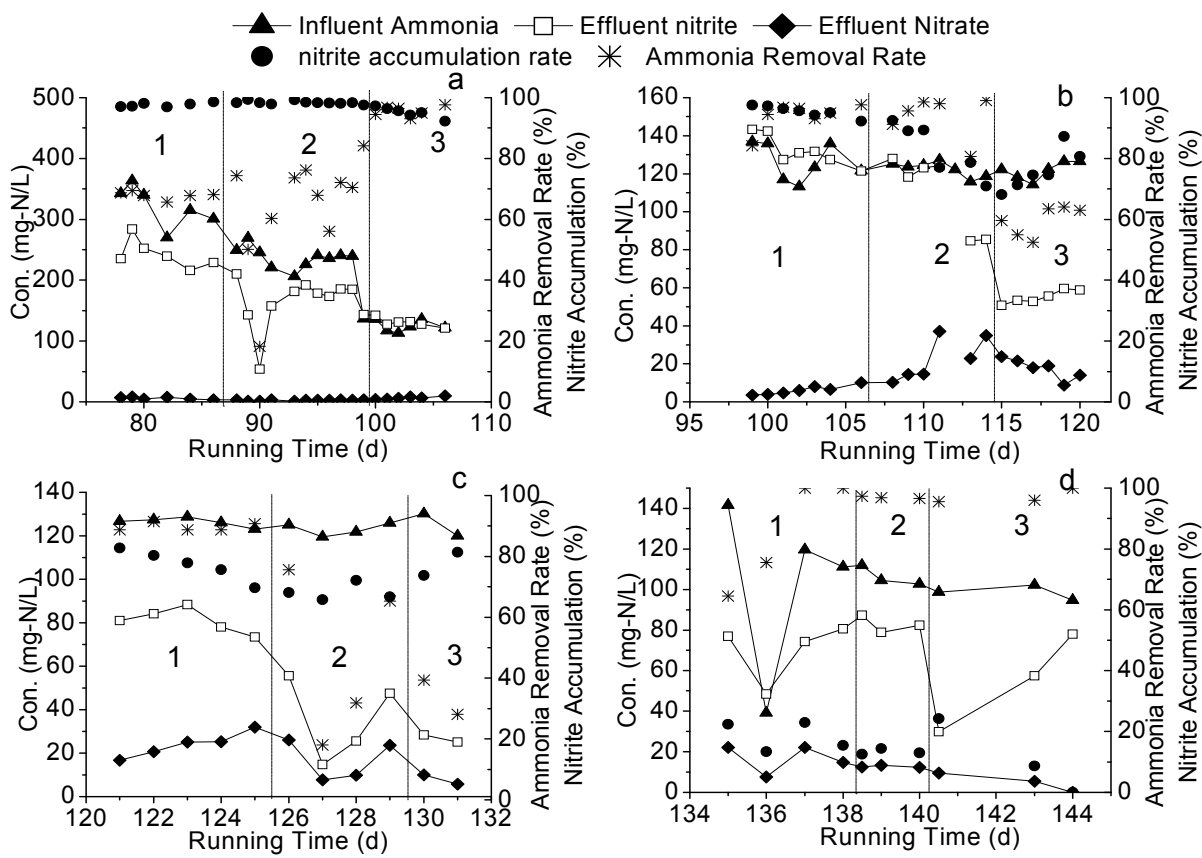

Figure 3

Nitrite oxidation under different (a) $\mathrm{NH}_{4}^{+}-\mathrm{N}$ concentrations, (b) temperature, (c) DO, (d) TOC concentrations $(1,2$ and $3=$ Phase 1,2 and 3 in each period) 
operation, the FBR regained partial nitrification and a high nitrite accumulation of above $80 \%$ for more than 260 days. The reactor achieved a quick recovery even after a long time of placement and TOC addition.

\section{Nitrification in Reactor B}

Reactor B was started up on Day 94 to treat the effluent of Reactor A. As shown in Fig. 5, the influent of Reactor B contained $\mathrm{NH}_{4}^{+}-\mathrm{N}, \mathrm{NO}_{2}^{-}-\mathrm{N}$ and $\mathrm{NO}_{3}^{-}-\mathrm{N}$. The influent $\mathrm{NH}_{4}^{+}-\mathrm{N}$ concentration was below $100 \mathrm{mg} \cdot \ell^{-1}$, much lower than that of Reactor A. After 50 days of operation, the effluent $\mathrm{NO}_{2}-\mathrm{N}$ concentration dropped below $20 \mathrm{mg} \cdot \ell^{-1}$ while nitrate concentration increased to $100 \mathrm{mg} \cdot \ell^{-1}$, indicating an increasing nitrite-oxidising activity. Compared to Reactor $\mathrm{A}$, the influent concentration of Reactor B was increased more slowly. Considering that the two reactors were filled with the same pellets, the increment speed of feed concentration may be crucial to the achievement of partial nitrification.

\section{Variation of different forms of nitrogen during the batch tests}

The first batch test of ammonium removal by the pellets in Reactor A was conducted on the Day 75 of operation. With the initial $\mathrm{NH}_{4}^{+}-\mathrm{N}$ concentration of $240 \mathrm{mg} \cdot \ell^{-1}$, the oxidation of $\mathrm{NH}_{4}^{+}-\mathrm{N}$ followed zero-order kinetics, and $\mathrm{NH}_{4}^{+}-\mathrm{N}$ was completely converted to $\mathrm{NO}_{2}^{-}-\mathrm{N}$ rather than $\mathrm{NO}_{3}^{-}-\mathrm{N}$ after $20 \mathrm{~h}$ (Fig. 6a). A stable partial nitrification was achieved in Reactor A.

The second batch test with Reactor $\mathrm{B}$ was carried out on Day 106 with initial $\mathrm{NH}_{4}^{+}{ }^{+} \mathrm{N}$ and $\mathrm{NO}_{2}{ }^{-} \mathrm{N}$ concentrations of 90 mg. $\ell^{-1}$ and $50 \mathrm{mg} \cdot \ell^{-1}$, respectively. Both $\mathrm{NH}_{4}{ }^{+}-\mathrm{N}^{-}$and $\mathrm{NO}_{2}{ }^{-}-\mathrm{N}$ were converted to $\mathrm{NO}_{3}-\mathrm{N}$ within $4 \mathrm{~h}$ (Fig. $6 \mathrm{~b}$ ), indicating that a complete nitrification was achieved in Reactor B.

The result of the third batch test shows that all of the ammonia was converted to nitrate when the organic matter was added (Figs. $6 \mathrm{c}$ and $6 \mathrm{~d}$ ). Nitrification was still achieved even at TOC concentration of $800 \mathrm{mg} \cdot \ell^{-1}$. However, the reaction rate was slow at higher TOC concentrations. Complete conversion of ammonium to nitrate was observed within $6 \mathrm{~h}$ at $400 \mathrm{mg} \cdot \ell^{-1}$ TOC but took more than $8 \mathrm{~h}$ at $800 \mathrm{mg} \cdot \ell^{-1}$ TOC.

\section{Possible reasons for partial nitrification by immobilised pellets}

The continuous reactor test demonstrated that Reactor A reached a stable partial nitrification. Considering the adequate DO (3-5 $\left.\mathrm{mg} \cdot \ell^{-1}\right)$ and uncontrolled $\mathrm{pH}$ in the reactors, the causal contribution of $\mathrm{DO}$ and $\mathrm{pH}$ can be excluded. The high $\mathrm{NO}_{2}^{-}-\mathrm{N}$ accumulation can, therefore, be attributed to two main factors.

First, $\mathrm{NO}_{2}-\mathrm{N}$ might have been washed out of the reactor before being oxidised to $\mathrm{NO}_{3}-\mathrm{N}$, due to the relatively short HRT. By controlling HRT of an immobilised fluidised bed reactor, Chen et al. (2006) achieved an optimal effect of partial nitrification. Chen found that nitrite was not oxidised into nitrate until all of the ammonium had been converted to nitrite; hence a desired partial nitrification could be obtained

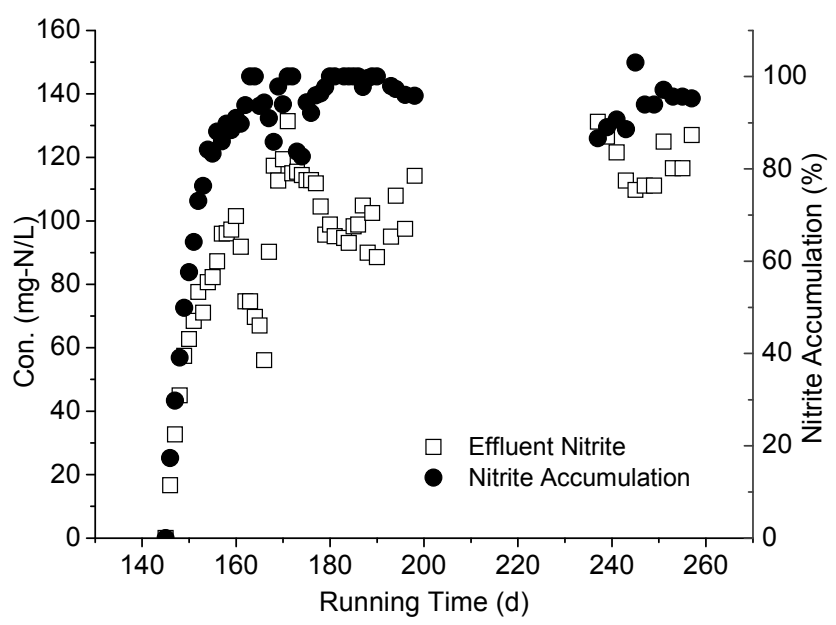

Figure 4

The recovery of nitrite accumulation after ceasing TOC addition
Figure 5

Variation of different forms of nitrogen in Reactor $B$
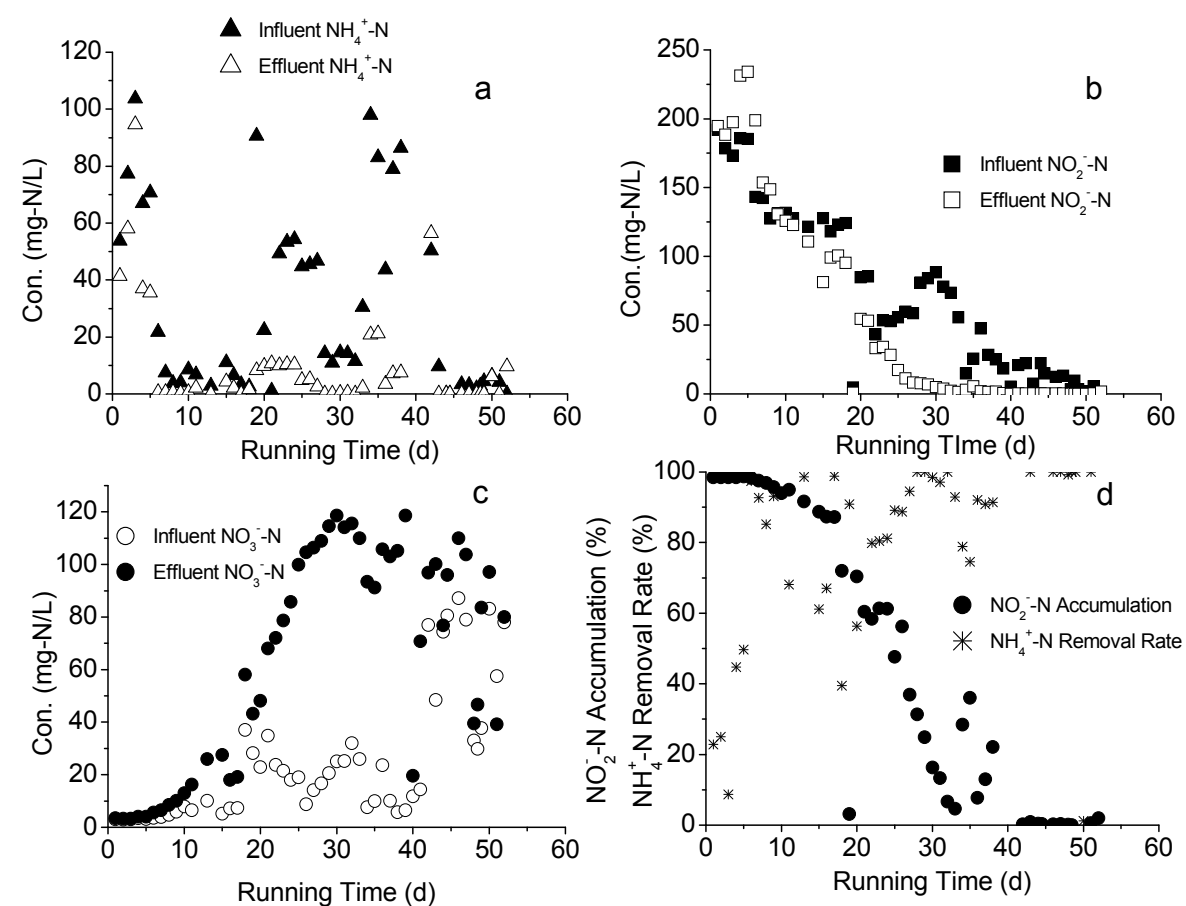

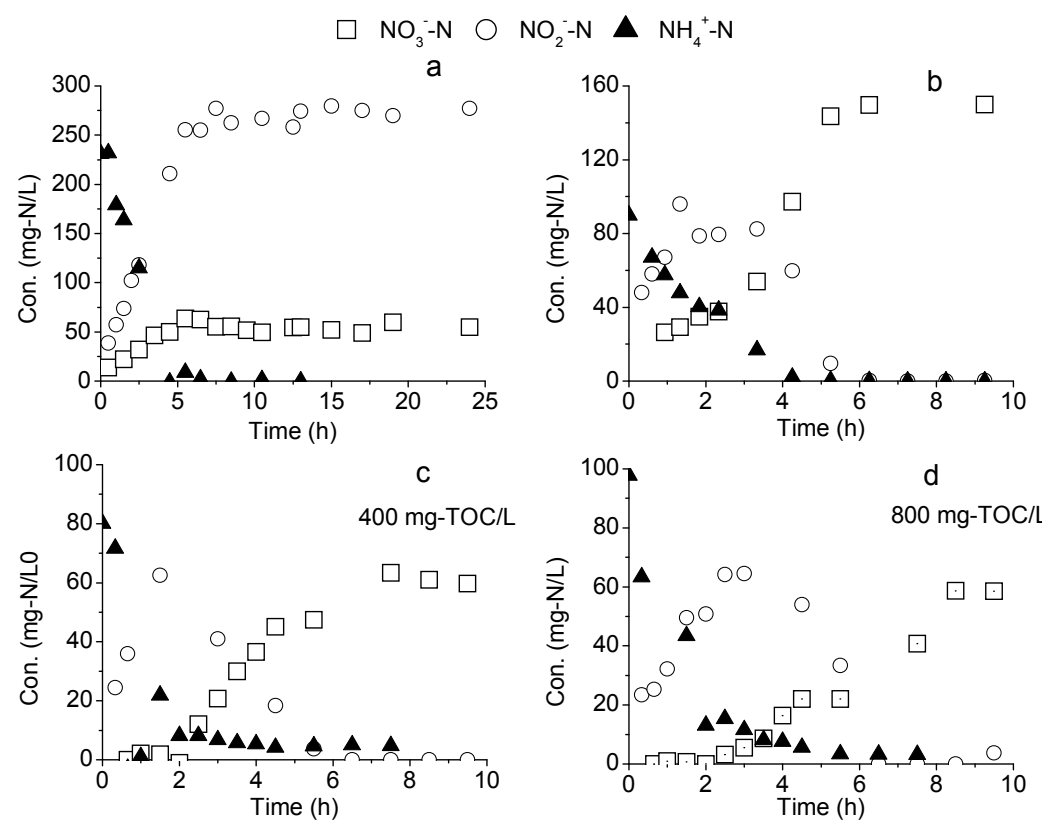

Variation of different forms of nitrogen during the batch test: (a) Reactor A, (b) Reactor B, (c) TOC: $400 \mathrm{mg} \cdot \ell^{-1},(d)$ TOC: $800 \mathrm{mg} \cdot \ell^{-1}$ if the HRT was controlled to allow only enough time for the ammonia to be oxidised into nitrite. However, the first batch test result, that almost all of the $\mathrm{NH}_{4}{ }^{+}-\mathrm{N}$ was converted to $\mathrm{NO}_{2}^{-}-\mathrm{N}$ rather than $\mathrm{NO}_{3}^{-}-\mathrm{N}$ after $20 \mathrm{~h}$ (Fig. 6a), demonstrated the achievement of a stable partial nitrification and excluded the possibility that partial nitrification was the result of a controlled HRT. Nevertheless, an enhanced partial nitrification could be achieved by controlling HRT in practice.

Second, NOB in the reactor might be inhibited by free ammonia (FA) and be outcompeted by AOB. Following the FA calculation, FA concentrations in our study mainly ranged from 0.1 to $4.82 \mathrm{mg} \cdot \ell^{-1}$. Isaka et al. (2007) suggested that FA concentrations higher than $0.1 \mathrm{mg} \cdot \ell^{-1}$ could contribute to the inhibition of NOB. According to Kim et al. (2005) and Yoon (2002), FA plays a greater inhibitory effect on the growth of NOB than AOB. The high FA levels caused by the rapid increase in influent $\mathrm{NH}_{4}^{+}-\mathrm{N}$ concentration may have inhibited the growth of NOB and, at the same time, caused AOB to predominate in the immobilised pellets. When AOB had gradually predominated over the limited NOB population in immobilised pellets, the degradation of $\mathrm{NH}_{4}^{+}-\mathrm{N}$ by accumulated AOB became the main nitrification process in the biological reactor, and an obvious accumulation of $\mathrm{NO}_{2}-\mathrm{N}$ could readily be maintained in the reactor for more than 260 days, even after a period of complete nitrification.

The growth rate of $\mathrm{AOB}$ is faster than that of $\mathrm{NOB}$ (0.019-0.092 $\mathrm{h}^{-1}$ for the AOB and $0.012-0.06 \mathrm{~h}^{-1}$ for the NOB) (Moussa et al., 2004; Van Loosdrecht and Jetten 1998), and a higher maximal specific growth rate of AOB than NOB was found at $20^{\circ} \mathrm{C}$ (Hellinga et al., 1998). Thus raising temperature can promote the growth rate of nitrifiers and therefore expand the difference in specific growth rate between AOB and NOB. However, in the present experiment, when the temperature increased from $24^{\circ} \mathrm{C}$ to $29^{\circ} \mathrm{C}$, no obvious variation of $\mathrm{NH}_{4}^{+}-\mathrm{N}$ removal efficiency was observed, except a slight decrease of nitrite accumulation. Therefore temperatures higher than $29^{\circ} \mathrm{C}$ are unnecessary to obtain a higher $\mathrm{NH}_{4}^{+}-\mathrm{N}$ removal efficiency. Removal efficiency of $\mathrm{NH}_{4}^{+}-\mathrm{N}$ decreased markedly and accumulation of $\mathrm{NO}_{2}-\mathrm{N}$ increased after the temperature dropped to $9^{\circ} \mathrm{C}$, which is contrary to Hyungseok et al.'s (1999) conclusion that partial nitrification could only be achieved when the temperature was above $15^{\circ} \mathrm{C}$. Although NOB had a relatively higher growth rate than $\mathrm{AOB}$ at lower temperatures, after a long operation period with a temperature higher than $20^{\circ} \mathrm{C}, \mathrm{NOB}$, which is present in much lower quantities, could not outcompete the large amount of accumulated AOB in the reactor. As a result, high nitrite accumulation was continually maintained when the temperature rapidly changed to lower than $9^{\circ} \mathrm{C}$. Low temperatures could decrease the activity of both $\mathrm{AOB}$ and $\mathrm{NOB}$, but maintaining a high running temperature increases the operation cost. From this study, the optimal recommended temperature is $24^{\circ} \mathrm{C}-29^{\circ} \mathrm{C}$.

Low DO level could be another key factor for achieving partial nitrification in some studies (Feng et al., 2007). NOB has less affinity for oxygen due to its relatively higher oxygen saturation coefficient compared with $\mathrm{AOB}\left(1.1\right.$ and $0.3 \mathrm{mg} \mathrm{O} \cdot \ell^{-1}$ for NOB and AOB, respectively (Wiesmann, 1994)). As a result, the activity of $\mathrm{NOB}$ was inhibited at low DO, while $\mathrm{AOB}$ was not severely impacted, and $\mathrm{NO}_{2}^{-}-\mathrm{N}$ accumulation was subsequently increased. However, due to the relatively low removal efficiency of $\mathrm{NH}_{4}^{+}-\mathrm{N}$ at low DO, effluent concentration of $\mathrm{NH}_{4}{ }^{+}-\mathrm{N}$ was too high to meet the water discharge standards. In addition, NOB was able to adapt to the low oxygen levels after a period of operation (Sliekers et al., 2005). Therefore maintaining low DO levels is not the most reliable and practical way to achieve stable and long-lasting partial nitrification. The rapid increase in influent ammonia concentration could be an effective way to achieve partial nitrification without affecting ammonia removal.

The organic matter markedly affected partial nitrification. According to Fang et al. (1993), the presence of carbohydrate such as glucose has a stimulatory effect on the activity of the nitrifiers. Results of the present experiment showed that glucose could stimulate the growth of NOB in the reactor. Since some NOB were facultative autotrophs (Starkenburg et al., 2006), nitrite oxidation was not directly affected by organic loading. Mosqura-Corral et al. (2005) found that the inhibitory effect of heterotrophs on nitrifiers could be minimised due to the high concentrations of ammonia in the liquid phase. Considering the effect of carbohydrate on partial nitrification, the process in this experiment is well-matched with the treatment of wastewaters containing high nitrogen and low organic carbon concentrations. The third batch test (Fig. 6d) showed that the reaction system has 


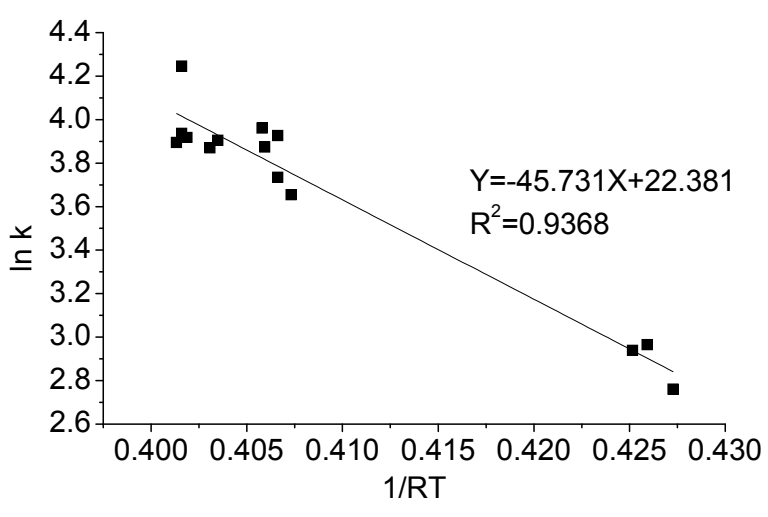

Figure 7

$E_{a}$ determination for ammonia oxidation reaction for partial nitrification

the ability to withstand organic shock loads, at least at $800 \mathrm{mg} \cdot \ell^{-1}$. This is probably because the pellets served as protection to the nitrifiers in the competition with heterotrophic bacteria under high concentrations of organics.

\section{Advantages of immobilisation}

Compared to activated sludge, biofilm and immobilised nitrifiers (Ciudad et al., 2007; Ruiz et al., 2003; Kim et al., 2000; Weon et al., 2004), the immobilised pellets with PAC addition have unique advantages, such as higher volumetric removal rate (the maximum rate approached $16.76 \mathrm{~g} \mathrm{~N} \cdot \ell^{-1} \cdot$ pellet $^{-1} \cdot \mathrm{d}^{-1}$ ), shorter acclimation period (7 days) and tolerance to high ammonium concentrations (up to $800 \mathrm{mg} \cdot \ell^{-1} \mathrm{TOC}$ ).

Data obtained from acclimation and continuous tests in Reactor A showed that the immobilised pellets with PAC have a higher nitrification rate than that reported in most of other studies, and a greater capability against shock loads than pellets without PAC addition. This suggests that PAC addition improves the performance of nitrification with immobilised pellets.

The activation energy of the ammonium oxidation process in Reactor A can be determined graphically by taking the natural logarithm of Arrhenius equation (Eq. (2)). The activation energy of ammonia oxidation in the temperature range $8.5-26.7^{\circ} \mathrm{C}$ was determined from the slope of the straight line and was $45.731 \mathrm{~kJ} \cdot \mathrm{mol}^{-1}$ (Fig. 7). The comparison of activation energies for immobilised nitrifiers reported for different studies is presented in Table 2. The activation energy of immobilised

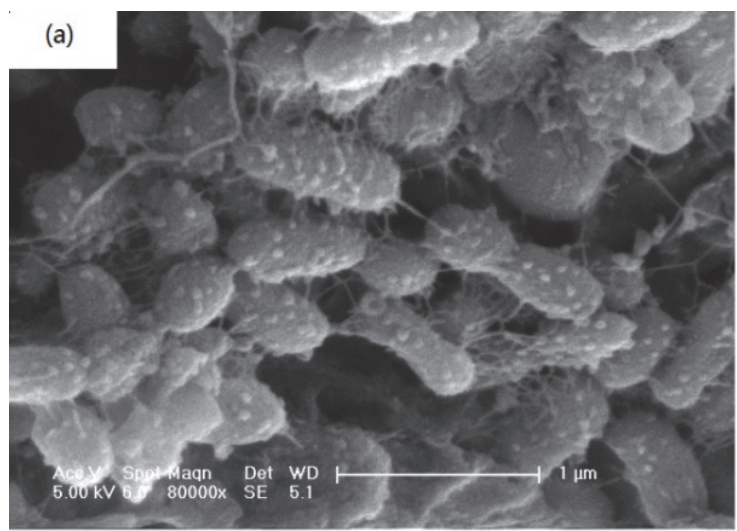

pellets was relatively lower than the values for both partial nitrification sludge (42-111.5 $\left.\mathrm{kJ} \cdot \mathrm{mol}^{-1}\right)$ and activated sludge $\left(87.1 \mathrm{~kJ} \cdot \mathrm{mol}^{-1}\right)$ under the same temperature conditions, as reported for other related studies. The nitrification process reported in this study was thus easier to achieve than reported elsewhere (Guo et al. 2010; Kim et al., 2008.)

\section{Bacterial morphology}

The SEM images (Fig. 8) show the differences between the microorganisms on the surface of the immobilised pellets in Reactor A and those present in the complete nitrification reactor used in our previous study (Wang, 2008). The microorganisms in the present study are ellipsoidal and coarse, with a shorter length $(0.5 \mu \mathrm{m})$, while microorganisms in Fig. $8 \mathrm{~b}$ are rod-shaped, smooth on the surface, and with a length of $1 \mu \mathrm{m}$. The microorganisms in the present study might be specific $\mathrm{AOB}$, while the long rod-shaped ones in the complete nitrification reactors are probably composed of NOB. To clarify this, the microorganisms found in this research were analysed by PCR-DGGE techniques.

\section{Analysis of microbial community}

Figure 9 presents the DGGE result of the samples taken from both partial and complete nitrification (Reactors A and B, respectively). The band patterns of $\mathrm{AOB}$ amplicons were almost unchanged in Samples \#4 to \#8 (Fig. 9a). This uniform pattern of $\mathrm{AOB}$ community structure reveals that influencing factors such as ammonia concentration, temperature and DO had little impact on the stability of the AOB community. Very weak bands appeared in Sample \#9, which was collected when glucose was added. This could probably be attributed to the impact of carbohydrates and competition from heterotrophs.

The band pattern for NOB amplicons of the samples from Reactor A was more complicated than that for samples from Reactor B. A notably different band was NOB-4, which appeared in all the samples from Reactor B but was absent in samples from Reactor A (Fig. 9b). The 4 bands, NOB-1 to 4 , were chosen for sequencing. Through gene blast, the partial sequence NOB- 4 was found to be highly similar to Nitrosomonas group and Nitrobacter Sp. 219 and Nitrobacter Sp. 263 , with a similarity of $100 \%$. In other words, the absence of Nitrobacter Sp. 219 and Nitrobacter Sp. 263 are likely to be the main reason for stable partial nitrification in Reactor A.

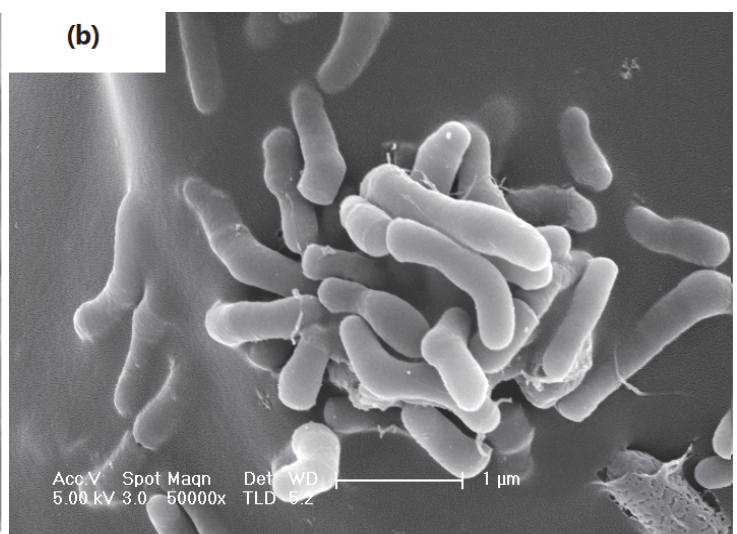

SEM pictures of the immobilised pellets from (a) partial nitrification reactor (b) completed nitrification reactor 


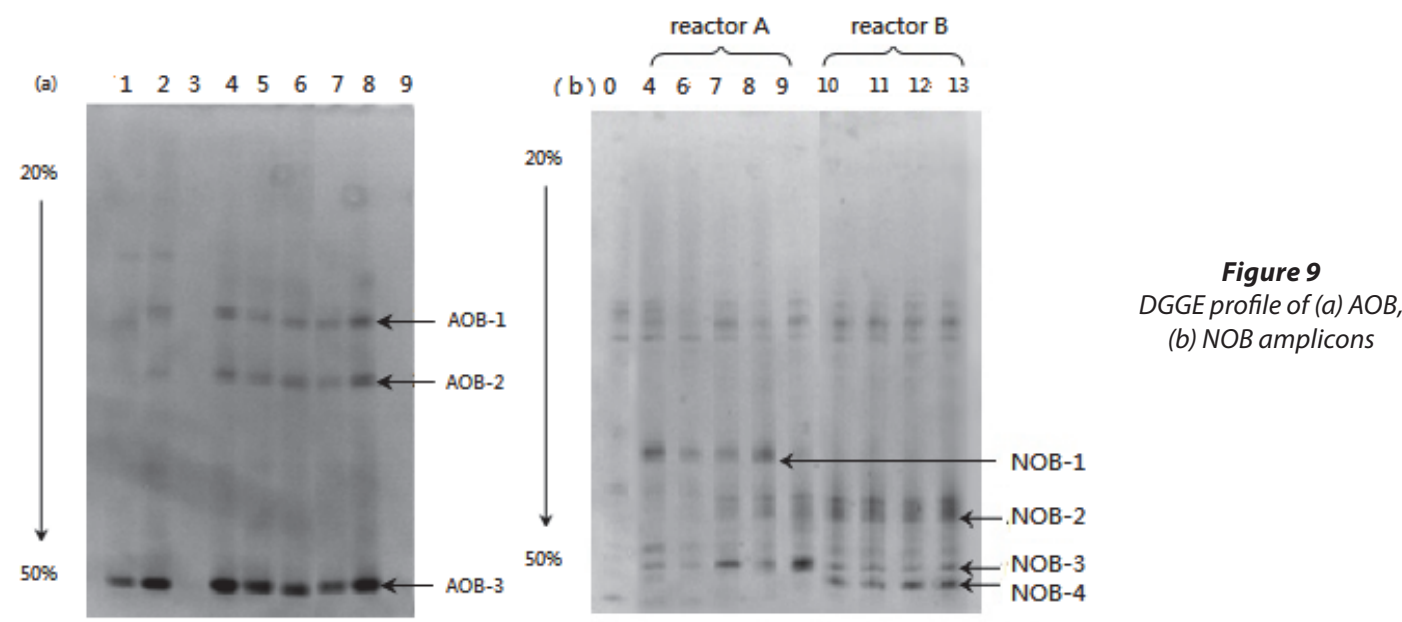

Connecting the whole study, we believe that the rapid increase in ammonia concentration may inhibit specific species of NOB, without which complete nitrification cannot be obtained. Since AOB are more tolerant to high levels of FA than NOB, after a long growing period they may have occupied most of the places inside and outside the pellets, leaving limited living space for NOB. Therefore, AOB became dominant even when the FA concentration decreased. In this case, the ammonia could only be oxidised to nitrite by large amounts of $\mathrm{AOB}$, and a high nitrite accumulation was achieved.

\section{CONCLUSION}

In this experiment, continuous and batch tests were carried out to investigate the partial nitrification process and its influencing factors. Sludge immobilisation with PAC addition was demonstrated to be an effective approach to improve $\mathrm{NH}_{4}{ }^{+} \mathrm{N}$ removal capacity.

Quickly increasing the influent concentration from 40 to $320 \mathrm{mg} \cdot \ell^{-1} \mathrm{NH}_{4}^{+}-\mathrm{N}$ caused a stable partial nitrification. Accumulation of $\mathrm{NO}_{2}^{-}-\mathrm{N}$ reached above $80 \%$ at $\mathrm{pH} 7.8-8.5$, DO of $3-5 \mathrm{mg} \cdot \ell^{-1}$ and temperature of $24-29^{\circ} \mathrm{C}$. HRT could be used as a flexible control parameter in the process to obtain a desired effect of partial nitrification. By adding organic matter such as glucose to the reaction system, $\mathrm{NO}_{2}-\mathrm{N}$ accumulation could be markedly decreased while the removal efficiency of $\mathrm{NH}_{4}^{+}-\mathrm{N}$ was promoted.

The possible reasons for partial denitrification were investigated and discussed. The PCR-DGGE results indicated that Nitrobacter Sp.219 and Nitrobacter Sp.263 were absent in the partial nitrification system. The rapid increase in feed concentration may inhibit these specific species of NOB, without which complete nitrification could not be obtained.

\section{ACKNOWLEDGEMENTS}

We gratefully acknowledge the support from the Instrumental Analysis centre of SJTU in the analysis of SEM samples. This study was financially supported by the Programme for New Century Excellent Talents in Universities of China (NCET-11-0320).

\section{REFERENCES}

ANTHONISEN AC, LOEHR BC, PRAKASAM TB and SRINATH EG (1976) Inhibition of nitrification by ammonia and nitrous acid.
J. Water Pollut. Control 48 835-852.

APHA (1995) Standard Methods for the Examination of Water and Wastewater (19 ${ }^{\text {th }}$ edn.). American Public Health Association (APHA), the American Water Works Association (AWWA), and the Water Environment Federation (WEF), Washington DC, USA.

CASSIDY MB, LEE H and TREVORS JT (1996) Environmental application of immobilised microbial cells: a review. J. Ind. Microbiol. 16 79-101.

CIUDAD G, GONZÁLEZ R, BORNHARDT C and ANTILEO C (2007) Modes of operation and $\mathrm{pH}$ control as enhancement factors for partial nitrification with oxygen transport limitation. Water Res. 40 4621-4629.

COLLIVER BB and STEPHENSON T (2000) Production of nitrogen oxide and dinitrogen oxide by autotrophic nitrifiers. Biotechnol. Adv. 18 219-232.

CHEN YJ, ZHANG ZJ and LI ZR (2006) Study on nitrification characteristics and systematic regulation of embedded immobilised Nitrobacteria. J. Water Resour. Prot. 22 56-59.

FANG HY, CHOU MS and HUANG CW (1993) Nitrification of ammonia-nitrogen in refinery wastewater. Water Res. 27 1761-1765.

FENG Y, TSENG S and HSIA T (2007) Partial nitrification of ammonium-rich wastewater as pretreatment for anaerobic ammonium oxidation (Anammox) using membrane aeration bioreactor. $J$. Biosci. Bioeng. 104 182-187.

FERAY C, VOLAT B, DERANGE V, CLAYS-JOSSERAND A and MONTUELLE B (1999) Assessment of three methods for detection and quantification of nitrite-oxidising bacteria and Nitrobacter in freshwater sediments. Microb. Ecol. 37 208-217.

GAO DW, PENG YZ and WU WM (2010) A kinetic model for biological nitrogen removal using shortcut nitrification-denitrification process in SBR. Environ. Sci. Technol. 44 (13) 5015-5021.

GARRIDO JM, VAN LOOSDRECHT MCM and HEIJNEN JJ (1997) Influence of dissolved oxygen concentration on nitrite accumulation in a biofilm airlift suspension reactor. Biotechnol. Bioeng. 53 $168-177$.

GUO JH, PENG YZ, HUANG H, WANG S, GE S, ZHANG J and WANG Z (2010) Short- and long-term effects of temperature on partial nitrification in a sequencing batch reactor treating domestic wastewater. J. Hazardous Mater. 179 471-479.

MUNZ G, LUBELLO C and OLESZKIEWICZ JA (2011) Factors affecting the growth rates of ammonium and nitrite oxidising bacteria. Chemosphere 83 (5) 720-725.

HELLINGA C, SCHELLEN A, MULDER JW, VAN LOOSDRECHT MCM and HEIJNEN JJ (1998) The SHARON process: an innovative method for nitrogen removal from ammonium-rich waste water. Water Sci. Technol. 37 135-142.

HICKEY RF, WU WM, VEIGA MC and JONES R (1998) The startup, operation and monitoring of high-rate anaerobic treatment systems. Water Sci. Technol. 24 207-255.

HYUNGSEOK Y (1999) Nitrogen removal from synthetic wastewater by simultaneous nitrification and denitrification via nitrite in an intermittently-aerated reactor. Water Res. 33 146-149. 
ISAKA K, YOSHIE S and SUMINO T (2007) Nitrification of landfill leachate using immobilized nitrifying bacteria at low temperatures. Biochem. Eng. J. 37 49-55.

KARTAL B, KUENEN JG and VAN LOOSDRECHT MCM (2010) Sewage treatment with anammox. Science 328 702-703.

KAMPSCHREUR MJ, TAN NCG, KLEEREBEZEM R, PICIOREANU C, JETTEN MSM and VAN LOOSDRECHT MCM (2008) Effect of dynamic process conditions on nitrogen oxides emission from a nitrifying culture. Environ. Sci. Technol. 42 429-435.

KAMPSCHREUR MJ, TEMMINK H, KLEEREBEZEM R, JETTEN MSM and VAN LOOSDRECHT MCM (2009) Nitrous oxide emission during wastewater treatment. Water Res. 43 4093-4103.

KAGEYAMA K, KOMATSU T and SUGA H (2003) Refined PCR protocol for detection of plant pathogens in soil. J. Gen. Plant Pathol. 69 153-160.

KIM DJ, AHN DH and LEE DI (2005) Effects of free ammonia and dissolved oxygen on nitrification and nitrite accumulation in a biofilm airlift reactor. Korean J. Chem. Eng. 22 85-90.

KIM JH, GUO XJ and PARK HS (2008) Comparison study of the effects of temperature and free ammonia concentration on nitrification and nitrite accumulation. Process Biochem. 43 154-160.

KIM SK, KONG I and LEE BH (2000) Removal of ammonium-N from a recirculation aquacultural system using an immobilised nitrifier. Aquacult. Eng. 21 (3) 139-150.

LI J, ZHANG Z J, LI Z, HUANG G and ABE N (2006) Removal of organic matter and nitrogen from distillery wastewater by a combination of methane fermentation and denitrification-nitrification processes. J. Environ. Sci. 18 654-659.

LIU Y and TAY JH (2004) State of the art of biogranulation technology for wastewater treatment. Biotechnol. Adv. 22 533-563.

MOSQURA-CORRAL A, GONZALEZ F and CAMPOS JL (2005) Partial nitrification in a SHARON reactor in the presence of salts and organic carbon compounds. Proc. Biochem. 40 3109-3118.

MOUSSA MS, HOOIJMANS CM and LUBBERDING HJ (2004) Modelling nitrification, heterotrophic growth and predation in activated sludge. Water Res. 39 5080-5098.

MUYZER G, DE WAAL EC and UITTERLINDEN AG (1993) Profiling of complex microbial populations by denaturing gradient gel electrophoresis analysis of polymerase chain reaction-amplified genes coding for 16S rRNA. Appl. Environ. Microbiol. 59 695-700.

NICOLAISEN MH and RAMSING NB (2002) Denaturing gradient gel electrophoresis (DGGE) approaches to study the diversity of ammonia-oxidising bacteria. J. Microbiol. Methods 50 189-203.

OĞUZ MT (2005) Investigation of nitrifying bacterial activities by monitoring nitrite oxidation, nitrate formation and carbon dioxide fixation during activated sludge treatment in the presence of metabolic inhibitors allylthiourea and azide. Erciyes Üniversitesi Fen Bilimleri Enstitüsü Dergisi 21 (1-2) 154-165.

RITTMANN BE and MCCARTY PL (2001) Environmental Biotechnology: Principles and Applications. McGraw-Hill, New York.

SANTOS V A P M DOS, TRAMPER J and WIJFFELS R H (1993) Simultaneous nitrification and denitrification using immobilised micro-organisms. Biomater. Artif. Cells Immobilisation Biotechnol. 21 317-322.

SLIEKERS AO, HAAIJER SC, STAFSNES MH, KUENEN JG and JETTEN MS (2005) Competition and coexistence of aerobic ammonium and nitrite-oxidising bacteria at low oxygen concentrations. Appl. Microbiol. Biotechnol. 68 808-817.

STARKENBURG SR, CHAIN PS, SAYAVEDRA-SOTO LA, HAUSER L, LAND ML, LARIMER FW, MALFATTI SA, KLOTZ MG, BOTTOMLEY PJ, ARP DJ and HICKEY WJ (2006) Genome sequence of the chemolithoautotrophic nitrite-oxidising bacterium Nitrobacter winogradskyi Nb-255. Appl. Environ. Microbiol. 72 2050-2063.

RUIZ G, JEISON D and CHAMY R (2003) Nitrification with high nitrite accumulation for the treatment of wastewater with high ammonia concentration. Water Res. 37 1371-1377.

QIAO XL, LIU Z, LIU ZW, ZENG YL and ZHANG ZJ (2010) Immobilisation of activated sludge in poly(ethylene glycol) by UV technology and its application in micro-polluted wastewater. Biochem. Eng. J. 50 71-76.

VAN LOOSDRECHT MCM and JETTEN MSM (1998)

Microbiological conversions in nitrogen removal. Water Sci. Technol. 38 1-7.

WANG L (2008) Study on the treatment of micro-polluted raw water by using immobilised microbiological pellets. Master's thesis, Shanghai Jiaotong University, China.

WANG YL (2010) Study on partial nitrification in the immobilisation biological reactor. Master's thesis, Shanghai Jiaotong University, China.

WIESMANN U (1994) Biological nitrogen removal from wastewater. Adv. Biochem. Eng./Biotechnol. 51 113-154.

YOON HJ (2002) A study of the nitrogen removal characteristics via nitrite accumulation of biofilm reactor system. Department of Environmental System Engineering, Hallym University, Korea.

ZHOU W, IMAI T, UKITA M, LI F and YUASA A (2006) Triggering forces for anaerobic granulation in UASB reactors. Process Biochem. 41 36-43.

ZHOU W, KAGEYAMA K, LI F and YUASA A (2007) Monitoring of microbiological water quality by real-time PCR. Environ. Technol. 28 545-553. 
http://dx.doi.org/10.4314/wsa.v39i2.13 Available on website http://www.wrc.org.za

ISSN 0378-4738 (Print) = Water SA Vol. 39 No. 2 April 2013 ISSN 1816-7950 (On-line) = Water SA Vol. 39 No. 2 April 2013 